\title{
Innovative architectural design development: the Arcbazar creative crowdsourcing contests perspective
}

\author{
Adriana Bujor ${ }^{1, *}$, and Silvia Avasilcai ${ }^{1}$ \\ 1“Gheorghe Asachi” Technical University of Iasi, Department of Engineering and Management, Romania
}

\begin{abstract}
Growth and value creation have become the dominant preoccupations for today's managers/companies. That is why they have increasingly embraced crowdsourcing and co-creation as business practices, especially online. If most of them aim to increase their performance with the help of these practices, there have been cases where they have been approached in critical moments, when various businesses have found themselves on the verge of collapse, as is the case with Legos. If crowdsourcing is about getting the services, ideas or content needed, by asking for contributions from a large group of people and especially from an online community rather than from traditional employees or suppliers, co-creation is considered to be the strongest business strategy, at the moment, to involve consumers in co-creating products, services, and experiences with a unique value for both parties. In this paper, architectural design crowdsourcing will be presented as an alternative method to the acquisition of traditional design, which can overcome the potential deficiencies, faced by this sector of the creative industries, and may bring smaller projects in the field of architectural practices.
\end{abstract}

\section{Introduction}

The term crowdsourcing, representing the combination of crowd and outsourcing, was first mentioned by author Jeff Howe in his article The Rising of Crowdsourcing in 2006 [1] and represents a fashionable business practice. Therefore, firstly, it is necessary to understand what outsourcing means.

According to the author James Bucki, outsourcing, also called contracting out, is a business practice used by businesses to reduce their costs or improve their efficiency by transferring tasks, operations, jobs, or processes to an outsourced (external) third party for a significant, established, period of time. The outsourced functions may be performed by third parties, whether onsite or off-site the business [2].

Since the beginning of the 21 st century, society, in general, and the structure of the market, in particular, has undergone a major transformation process, according to Prahalad, et al., with a shift in power from those businesses that have determined which are their customers' needs, in order to manipulate the demand to satisfy their offers to networks of customers and manufacturers that create value together [3].

Thus, co-creation represent another business strategy, as crowdsourcing, that managers and entrepreneurs have embraced and adopted for their business growth, using mostly creative online platforms.

Once implemented, both crowdsourcing and cocreation, as open innovation strategies for a business performance growth, offers many benefits to manufacturers.

\section{Crowdsourcing - definition and meanings}

Crowdsourcing, in short, is defined as a method that uses people around the world to help accomplish a particular task. The masses are invited, in various, projects to propose and even help develop a new product or service, refine a project, calculate or obtain different algorithms, or assist in providing, organizing, or evaluating significant amounts of information in viable data [4].

Nowadays, crowdsourcing is used by almost all industries in order to face the changes in the market, to align with the new trends, and to register a better performance, in the end.

As highlighted by Pripic at.al., most recently research on crowdsourcing considers that there are three types of crowdsourcing applications that can be used by organizations: virtual labor markets, tournamentcrowdsourcing, and open collaboration [5]. Each of these types can be compared along the following universal characteristics: the cost of using a crowdsourcing technique, the anonymity of crowdsourcing participants, the scale of crowd size, the IT structure of crowdsourcing application, the time required to implement crowdsourcing, the magnitude of crowdsourcing tasks, and the reliability of the crowdsourcing technique.

One of the most popular examples of crowdsourcing, Wikipedia, is a platform developed through the voluntary collaboration of a large number of

\footnotetext{
* Corresponding author: adbujor@gmail.com
} 
people, which are the creators and editors of its extensive web content.

\section{Co-creation - definition and meanings}

Seen as an art, an initiative of management, or an economic strategy, co-creation successfully brings different parties together: a company and a community of customers, in order to jointly create a mutually valued good/service, as C.K. Prahalad, and V. Ramaswamy underlines [6].

C.K. Prahalad and Venkat Ramaswamy describe cocreation as "viewing markets as forums for organizations and active customers to share, combine and renew each others resources and capabilities in order to create value through new forms of interaction and learning" [3].

According to Piller, through the open line created for their customers by those manufacturers that have embraced co-creation, businesses have access to ideas for new products or for improving others, even to complete models/designs. Thus, helping customers build networks, organize themselves in communities, and express their commitment to a particular project, enables companies to transform market research spending into sales [7].

Table 1. The concept of co-creation [7].

\begin{tabular}{|c|c|}
\hline What Co-creation IS NOT & What Co-creation IS \\
\hline $\begin{array}{l}\text { Customer focus } \\
\text { Customer is king or } \\
\text { customer is always right }\end{array}$ & $\begin{array}{l}\text { Co-creation is about joint } \\
\text { creation of value by the } \\
\text { company and the customer. It } \\
\text { is not the firm trying to } \\
\text { please the customer. }\end{array}$ \\
\hline $\begin{array}{l}\text { Delivering good customer } \\
\text { service or pampering the } \\
\text { customer with lavish } \\
\text { customer service }\end{array}$ & $\begin{array}{l}\text { Allowing the customer to co- } \\
\text { construct the service } \\
\text { experience to suit her context }\end{array}$ \\
\hline $\begin{array}{l}\text { Mass customization of } \\
\text { offerings that suit the } \\
\text { industry's supply chain }\end{array}$ & $\begin{array}{l}\text { Joint problem definition and } \\
\text { problem solving }\end{array}$ \\
\hline $\begin{array}{l}\text { Transfer of activities from } \\
\text { the firm to the customer as in } \\
\text { self-service }\end{array}$ & $\begin{array}{l}\text { Creating an experience } \\
\text { environment in which } \\
\text { consumers can have active } \\
\text { dialogue and co-construct } \\
\text { personalized experiences; } \\
\text { product may be the same (e.g. } \\
\text { Lego Mindstorms) but } \\
\text { customers can construct } \\
\text { different experiences }\end{array}$ \\
\hline Product variety & Experience variety \\
\hline Segment of one & Experience of one \\
\hline Meticulous Market research & $\begin{array}{l}\text { Experiencing the business as } \\
\text { consumers do in real time } \\
\text { Continuous dialogue }\end{array}$ \\
\hline Staging experiences & $\begin{array}{l}\text { Co-constructing personalized } \\
\text { experiences }\end{array}$ \\
\hline $\begin{array}{l}\text { Demand-side innovation for } \\
\text { new products and services }\end{array}$ & $\begin{array}{l}\text { Innovating experience } \\
\text { environments for new co- } \\
\text { creation experiences. }\end{array}$ \\
\hline
\end{tabular}

However, it does not mean that co-creation of customers is always beneficial. The development of conventional products and customer co-creation should be seen as complementary rather than substitute, and very important, according to C.K. Prahalad, and V. Ramaswamy, is to understand what is and what is not cocreation [6].

\section{Crowdsourcing and co-creation in creative industries}

Creative industries are those industries which combine the creation, production, and commercialization of creative elements [8], comprising all that is produced by artistic and scientific creativity and has industrial potential, enters in the economic circuit, produces value, generates public income through taxes, creates jobs and profit, and was proved that helps to national and regional development [9].

During the years, different researches have proven that creative businesses can save the economy at the national or regional level, mainly where the traditional economies based on agriculture, industry or commerce has failed. Representing the happy combination of both qualities: that of the artist and that of the businessman [], creative businesses are increasingly becoming important components of modern post-industrial knowledge-based economies [9].

Even though they usually are based on the individual talent, according to the DCMS (UK) definition of creative industries, and on creative content, they are also adopting new business strategies, such as open innovation. By using these new innovative strategies these industries demonstrate that they have also understood the importance of the crowd, the power of its voice and role in delivering outputs to meet the demands of increasingly competitive markets.

Thus, more and more, creative businesses have also started to gather ideas for innovation from customers or stakeholders through their involvement into the early stages of the adopted open innovation process, either through crowdsourcing, or co-creation. In fact, it has been demonstrated that their ideas outline their needs, desires, and have been described as need for information [10]. Customers, and stakeholders generally also offer ideas that have been called solution information, which is not just need information but also customer-oriented proposals that describe how ideas can be transformed into marketable products [10].

In the field of architectural design, sector that belongs to the creative industries, the traditional model acquisition is mainly for all smaller-scale projects ineffective, unaffordable, and unattainable. There are different reasons why clients are not attracted to the idea to pursue architectural design services, namely:

- the way of finding an architectural designer: via word of mouth, or through friends and family,

- the fees of service providers which can be quite high (can range between 10 and $15 \%$ of the construction cost), - the predominant fear that in the end, after all the hard work and cost, the client might not be happy with the singular design they get from only one designer [4].

Thus all of the above make room for disruptive business models in order to make it all easier for both clients and designers. Arcbazar is the first architectural 
design crowdsourcing platform, that right from the beginning it has registered success, but also critics from professionals in the field, which consider that by offering free ideas the company placed no weight on value [11].

\section{Arcbazar case study - an example of a design crowdsoucing platform}

Access to architectural design services has been historically excessively high. As a result, $89 \%$ of the annual housing improvement projects are completed without a project, according to Modern Ventures [12]. This often leads to inappropriate expectations and costly mistakes by all parties to trading.

\subsection{About Arcbazar}

Considering these prohibitive costs and taking into account the needs and wishes of those interested in design and architecture services, Arcbazar was founded in 2010, in Cambridge, Massachusetts, with the aim to help designers and architectures, especially the young ones, to find exciting and challenging design opportunities, according to the platform [13].

Being the first-of-its-kind online competition website, as the company claims [13], Arcbazar offers a market for real estate professionals and consumers to present their home and property redevelopment project, where thousands of architects compete for to provide the best performance in a fraction of what traditional architectural services are taxing, as mentioned by Modern Ventures [12].

The idea for arcbazar.com was developed after the founders, both executives and web developers, noticed that:

- too often customers could not find a simple and affordable way to find competitive architectural design services, and, at the same time,

- designers have a hard time getting in touch with customers and using their design talent [13].

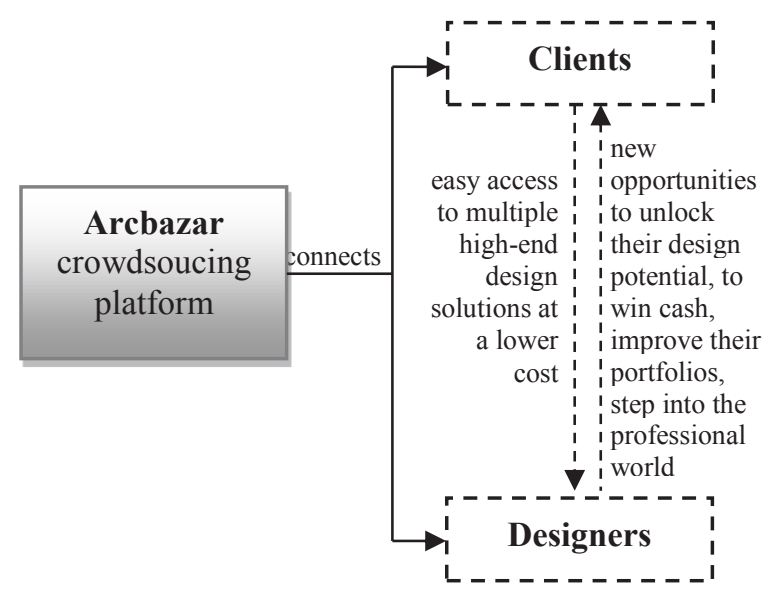

Fig. 1. Arcbazar's main benefits to its stakeholders [14].

The name of the platform, Arcbazar, is inspired by the idea of an architecture bazaar, wanting to be an energetic, dynamic space for changing and negotiating design and architecture services, for which the founder,
Imdat As, and his team work constantly to match designers with exciting projects of site customers, as declared on the platform. [13].

\subsection{Arcbazar business model}

Anyone can start a design competition using the Arcbazar crowdsourcing platform. Competitions can be of various types, from small to medium scale, including: remodeling jobs (of an attic, basement, bathroom, and kitchen, or of an entire apartment), office spaces, additions (e.g. a room addition to the house), retail, landscape (for backyard, front yard, or other open areas/spaces) or any other architectural project (new construction) [14][15].

The arcbazar.com is user-friendly built, with an easy and intuitive interface, and diverse competition tools in order to help clients better describe their dream design challenges. All competition projects are verified by the company, safety, and privacy being its top priorities [16].

There are three important steps to be followed by both clients and designers in order to participate to a design competition, starting from the client's dream (design competition's input) to the final chosen project (design competition's output).

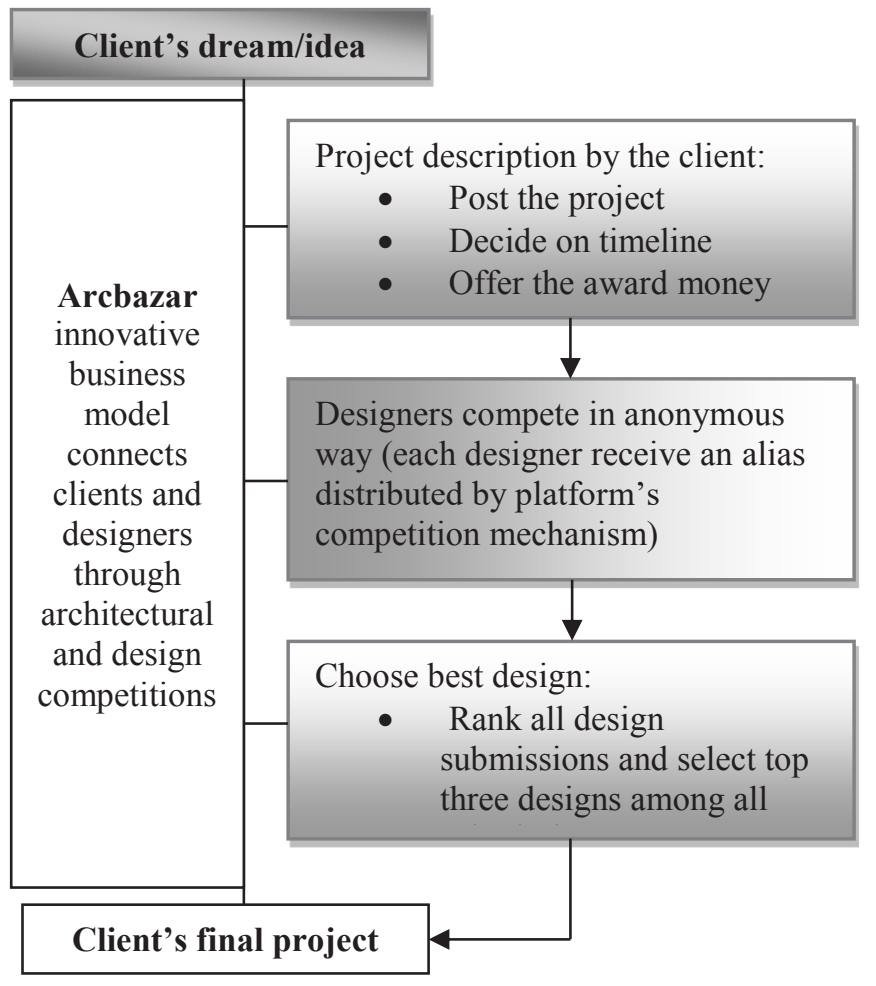

Fig. 2. Arcbazar's design competition steps [16].

Arcbazar registration is free to all stakeholders. As they begin to upload details about their projects, clients are helped by the company to establish the award money, by suggesting how much the prize should be. Some clients offer less, according to Ana Batista Company's spokesperson, up to the $\$ 250$ which is the minimum required by the site. Others decide to offer triple of what they are being suggested, hoping to get a variety of highquality designs [17]. The company's suggestions on the award money are based on different indicators, such as the 
complexity, scale, type, deliverables, and duration of a competition [15].

The platform is provided with a client-centered selection process that has the goal of controlling entries. In the process of choosing the final offer, the client must evaluate the 10 average proposals based on cost, schedule and proposal quality. The client performs a ranking of submissions, the first three being the one that collects the prize for the project, as it follows: $60 \%$ for the first place, $30 \%$ for the second and $10 \%$ for the third [18].

The process ends with ArcBazar automatically completing a set of documents and deliverables needed to complete the project.

\section{Conclusions}

The advantage of ArcBazar consists in the existence of the possibility to choose from architectural or quality design firms, lower or competitive costs, and faster delivery of architectural design.

Despite criticism, ArcBazar promotes enhanced access to high-quality/professional architecture or design services as a benefit to platform users.

All the data offered by the platform, together with the testimonials, proves that the decision to use crowdsourcing as an alternative for the traditional business model in creative industries, architecture, and design, in this case, was a right one to take by the founder. Thus, at the moment, the platform has managed to attract:

- $1,000,000$ total views

- $1,000+$ competitions

- 50,000+ projects,

- $190+$ participant countries.

The potential for growth still exists and is becoming more and more exciting once the platform becomes known through different advertising channels.

\section{Acknowledgment}

This work was supported by a grant of the Romanian National Authority for Scientific Research and Innovation, CNCS/CCCDI - UEFISCDI, project number PN-III-P2-2.1PED-2016-0689, within PNCDI III.

\section{References}

1. M. Rouse, Retrived from TechTarget web site, www.searchcio.techtarget.com/definition/crowdsour cing (2017)

2. J. Bucki, Retrived from The Balance web site, https://www.thebalance.com/what-is-outsourcing2533662 (2018)

3. C.K. Prahalad, and V. Ramaswamy, The Future of Competition: Co-Creating Unique Value with Customers, Boston, MA: Harvard Business School Press (2004).
4. A. Imdat, and A. Maria, Crowdsourcing Architecture: A Disruptive Model in Architectural Practice, ACADIA 12: Synthetic Digital Ecologies, San Francisco 18-21 October, 2012, pp. 439-443.

5. J. Prpic, and P. Shukla, Crowd Science: Measurements, Models, and Methods, https://arxiv.org/ftp/arxiv/papers/1702/1702.04221.p df

6. C.K. Prahalad, and V. Ramaswamy, Co-Creation Experiences: the Next Practice Value in Creation, Journal of Interactive Marketing, vol. 18, no. 3 (2004)

7. F.T. Piller, Open Innovation with Customers: Crowdsourcing and Co-creation at Threadless, SSRN Electronic Journal (2010)

8. A. Bujor, and S. Avasilcai, Creative industries as a growth driver: an overview, Proceedings of MakeLearn: Management, Knowledge and Learning International Conference, pp. 1725-1731, 25 - 28 Iunie, Portoroz, Slovenia (2015).

9. A. Bujor, and S. Avasilcai, Creative Entrepreneurship in Europe: A Framework of Analysis, Annals of The Oradea University, Fascicle of Management and Technological Engineering, B+, Vol. XXIII, nr. XIII, issue 1, pp. $151-156$ (2014).

10. A. Bujor, S. Avasilcai, Creativity and Innovation by Empowering the Customer: The Case of Mulino Bianco. Part I: Organisational Innovation Context, IOP Conference Series: Materials Science and Engineering, Vol. 95, pag. 012146, DOI: http://dx.doi.org/10.1088/1757-899X/95/1/012146, indexed ISI Web of Science (2015).

11. The Architects's Journal, https://www.architectsjournal.co.uk/news/dailynews/architecture-crowd-sourcing-websitecriticised/8620481.article (2011)

12. Modern Ventures, Arcbazar Pilot Program https://www.moderneventures.com/arcbazarpilot/ (2018)

13. Arcbazar, About us, https://www.arcbazar.com/about (2018)

14. Crunchbase, Organization: arcbazar.com, https://www.crunchbase.com/organization/arcbazarcom\#section-overview (2018)

15. Arcbazar, FAQ for Clients, https://www.arcbazar.com/faq-clients (2018)

16. Arcbazar, How it works, https://www.arcbazar.com/howitworks (2018)

17. The Orange County Register, https://www.ocregister.com/2014/02/22/architectsmiffed-at-website-that-offers-low-cost-bids/ (2014)

18. Digital Transformation and Innovation, https://digit.hbs.org/submission/arcbazarcrowdsourcing-design/ (2017) 